\title{
Skin lesions in humans bitten by European pigeon tick Argas reflexus (Fab.) (Ixodida: Argasidae) massively occurring in the Upper Silesian conurbation of south-west Poland
}

\author{
Alicja Buczek ${ }^{1, A-F}$, Katarzyna Bartosik',A,C-F , Dorota Kulina ${ }^{2, B-D, F}$, \\ Magdalena Raszewska-Famielec ${ }^{3, C-F}$, Adam Borzęcki ${ }^{3, C-F}$ \\ ${ }^{1}$ Chair and Department of Biology and Parasitology, Medical University, Lublin, Poland \\ ${ }^{2}$ Department of Basic Nursing and Medical Teaching, Medical University, Lublin, Poland \\ ${ }^{3}$ Med-Laser Non-Public Health Care Centre, Lublin, Poland \\ A - Research concept and design; B - Collection and/or assembly of data; C - Data analysis and interpretation; \\ $D$ - Writing the article; $E$ - Critical revision of the article; $F$ - Final approval of article \\ Buczek A, Bartosik K, Kulina D, Raszewska-Famielec M, Borzęcki A. Skin lesions in humans bitten by European pigeon tick Argas reflexus (Fab.) \\ (Ixodida: Argasidae) massively occurring in the Upper Silesian conurbation of south-west Poland. Ann Agric Environ Med. 2018; 25(2): 234-240. \\ doi: $10.26444 /$ aaem $/ 74137$
}

\begin{abstract}
Introduction and objective. The great number of pigeon populations in many European cities promotes the spread of the European pigeon tick (Argas reflexus), the bites of which cause local and systemic reactions. The aim was to study the occurrence of $A$. reflexus in several cities of Upper Silesia, and skin lesions caused by $A$. reflexus tick bites in humans.

Materials and method. The results of investigations carried out in 1995-2002 in five cities located in the Upper Silesian conurbation are presented. Specimens of $A$. reflexus were collected for one hour in attics and lofts inhabited by these ticks. A history of skin lesions caused by bites was taken from residents who had been infested by $A$. reflexus. The development of skin lesions was monitored for three months in two individuals who had been bitten several times by these arthropods.

Results. In the localities, 987 A. reflexus specimens were collected, including 334 females, 269 males, and 384 various nymphal stages. Within one hour, 38-109 ticks specimens were collected at the study sites. Cases of attacks by unengorged A. reflexus were reported in all the habitats located in the residential buildings; the ticks were also found in residents' flats and in staircases. Residents who had been repeatedly attacked by European pigeon ticks developed a strong inflammatory reaction to the components of tick saliva, and had purple papules with necrosis in the centre of the lesion. The tick bite areas exhibited scars and hyperpigmentation.

Conclusions. Individuals attacked by A. reflexus several times are at risk of development of severe persistent local reactions to bites. Pigeon ticks, trophically associated with pigeons present abundantly in the Upper Silesian conurbation and other European urban habitats, pose a serious threat to public health.
\end{abstract}

Key words

Public Health, skin lesions, urban environment, Argas reflexus, European pigeon tick, pests

\section{INTRODUCTION}

The European pigeon tick (Argas reflexus) is an element of the fauna of many European cities where it poses a major threat to public health [1-3]. The first information about the appearance of the European pigeon tick in residential buildings and human infestations dates back to the late $19^{\text {th }}$ and early $20^{\text {th }}$ centuries $[4,5]$. Since then, similar cases have been reported from different countries, usually upon tick infestations of humans and development of symptoms of allergic reactions in response to the salivary components, which exhibit strong allergenic properties $[6,7]$. To-date, the occurrence of $A$. reflexus has been confirmed in several cities in Poland (Fig. 1).

European pigeon ticks have been found near pigeons' nesting sites in church towers as well as attics and lofts of

Address for correspondence: Alicja Buczek, Medical University, Chair and Department of Biology and Parasitology, ul. Radziwiłłowska 11, 20-080 Lublin, Poland

e-mail: alicja.buczek@umlub.pl

Received: 25.04.2017; accepted: 27.05.2017; first published on 03.10.2017 buildings $[8,9]$, from where they entered areas inhabited by residents. The relatively small number of recorded pigeon tick attacks on man, in comparison with their high abundance in the habitats, may be related to the fact that allergic reactions developing in individuals bitten by $A$. reflexus can be erroneously assigned to other arthropods (e.g. bed bug Cimex lectularius, red mite Dermanyssus gallinae) or chemical agents. In many cases, the cause of the skin lesions is unrecognised and the patient receives symptomatic treatment [10]. These difficulties are mainly related to the fact that pigeon ticks are not active during daytime. They attack the host only at night, and the stages that parasitize humans most frequently, i.e. nymphs and adults, feed for a short time - ca. 1.5-2 hours [11]. When engorged, they hide deep in wall and furniture cracks and slits; only hungry specimens leave the hiding place to find a new source of food. As shown by Boxler et al. [12], among the several stimuli relevant for ticks, e.g. living nestlings as well as begging calls, body heat, smell, host breath, and tick faeces, heat is the sole stimulus that plays an important role in host localisation by $A$. reflexus. The tick reacts to this stimulus at a distance of several centimetres. 


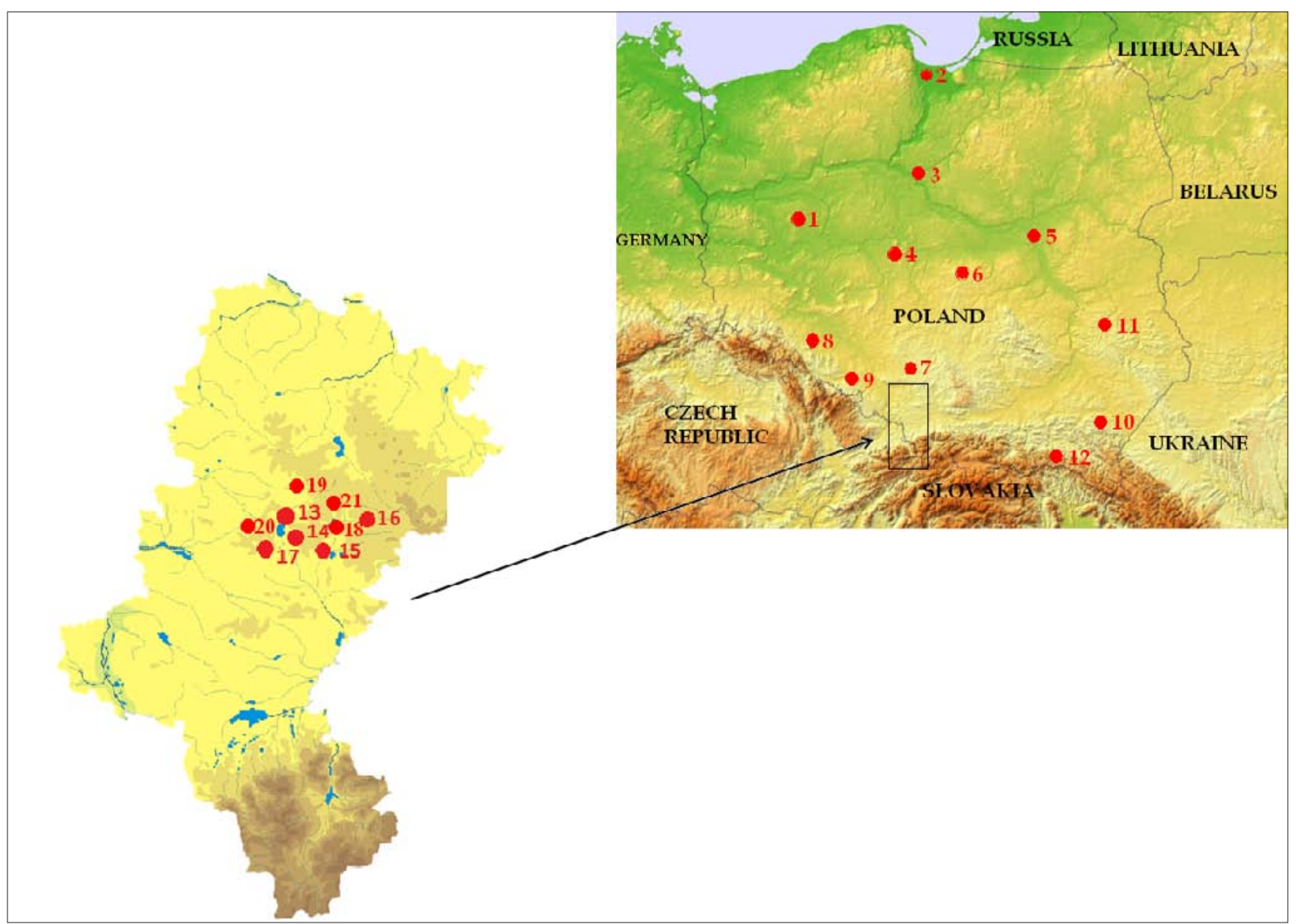

Figure 1. Localities of the European pigeon tick A. reflexus in Poland:

1) Rafalski 1954 Pol Pismo Entomol 24: 165-168;2) Wegner 1973 [54]; Izdebska et al. 2008 [29]; 3) Wójcik et al. 2001 Wiad Parazytol 47: 61-65;4) Wójcik personal communication; 5) Buczek et al. 1997 Ann Med Siles 33: 187-203; 6) Grzywacz and Kuźmicki 1975 Wiad Lek 28: 1571-1577; 7) Buczek and Bartosik 2011 [20]; 8) Grzywiński 1970 Wiad Parazytol 16: 457-461, Żukowski 1985 Proceedings of the Vth Symposium Med Vet Acaroentomol, Gdańsk: 64; 9) Kędzierzyn-Koźle Buczek et al. 2011 [21]; 10) Buczek and Magdoń 2000 [27]; 11) Buczek and Bartosik 2011 [20]; 12) Tylewska-Wierzbanowska et al. 1996 Przegl Epidemiol 50: 245-251; 13) Grzybek et al. 1973 [23]; 14) Siuda 1984, present study [16]; 15) Siuda 1993 [17]; 16) Buczek et al. 1997 Ann Med Siles 33: 187-203, present study; 17) Siuda 1984 [16]; 18) Siuda 1984 [16], Buczek and Solarz 1993 [10]; 19) present study; 20) Buczek et al. 1997 Ann Med Siles 33: 187-203; 21) present study.

A. reflexus is trophically associated with feral pigeons (Columba livia var. domestica), although it can search for other hosts in the absence of birds or at an increased density of ticks [9, 13-19]. Ticks leave pigeons' nesting sites and enter flats through open windows, doors, ventilation systems, and cracks in the walls [20,21]. Invasions of the European pigeon tick in flats are often noted after removal of pigeons from attics and during reconstruction of buildings or other construction work $[4,10,19,22]$. Residents of flats located on higher floors near lofts or attics adapted for residential purposes are most frequently infested by $A$. reflexus $[9,10$, 19, 21, 23-29].

The great number of pigeons in the urban environments (e.g., cities, towns, docks, and others human developments) $[30,31]$ and the constant growth of their population supported by food availability and favourable nesting conditions in all seasons of the year, accompanied by the absence of food predators and microorganisms $[32,33]$, can promote expansion of the occurrence range of the European pigeon tick.

\section{OBJECTIVES}

The persistence of an abundant $A$. reflexus population in cities is also determined by the biological traits of the tick species. These include the ability to survive even in the extreme conditions or unavailability of hosts, foetal and extraembryonic development with utilisation of energy reserves accumulated by previous developmental stages, and high adaptability. Therefore, it is necessary to disseminate information on $A$. reflexus attacks in humans and reactions to tick bites, which can help to identify the causes of the disease symptoms in patients and alleviate the effects of parasitism of these soft ticks. The article presents the results of studies of the occurrence of $A$. reflexus in several cities of Upper Silesia, and the skin lesions caused by A. reflexus tick bites in humans.

\section{MATERIALS AND METHOD}

The study was carried out in 1995-2002 in five cities, Katowice, Bytom, Chorzów, Dąbrowa Górnicza and Świętochłowice, located in the Upper Silesian conurbation (southwestern Poland), which is composed of 19 bordering cities of the 

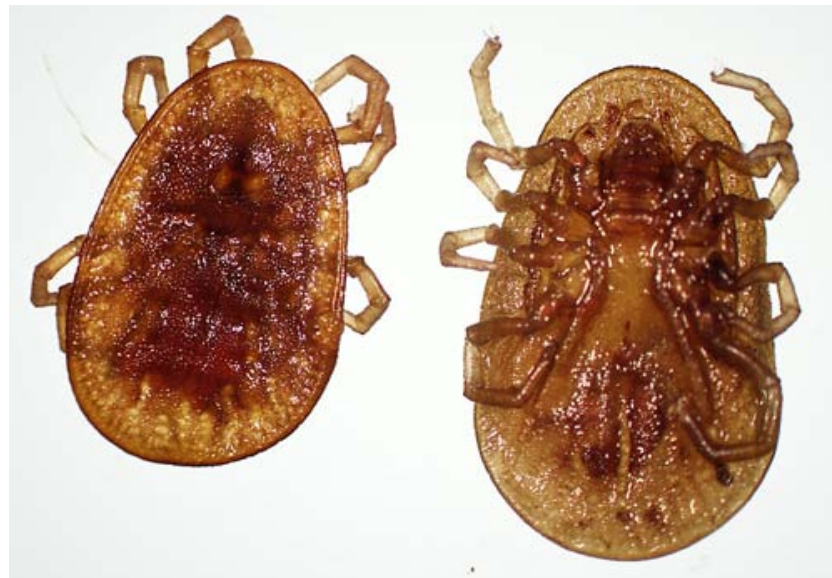

a
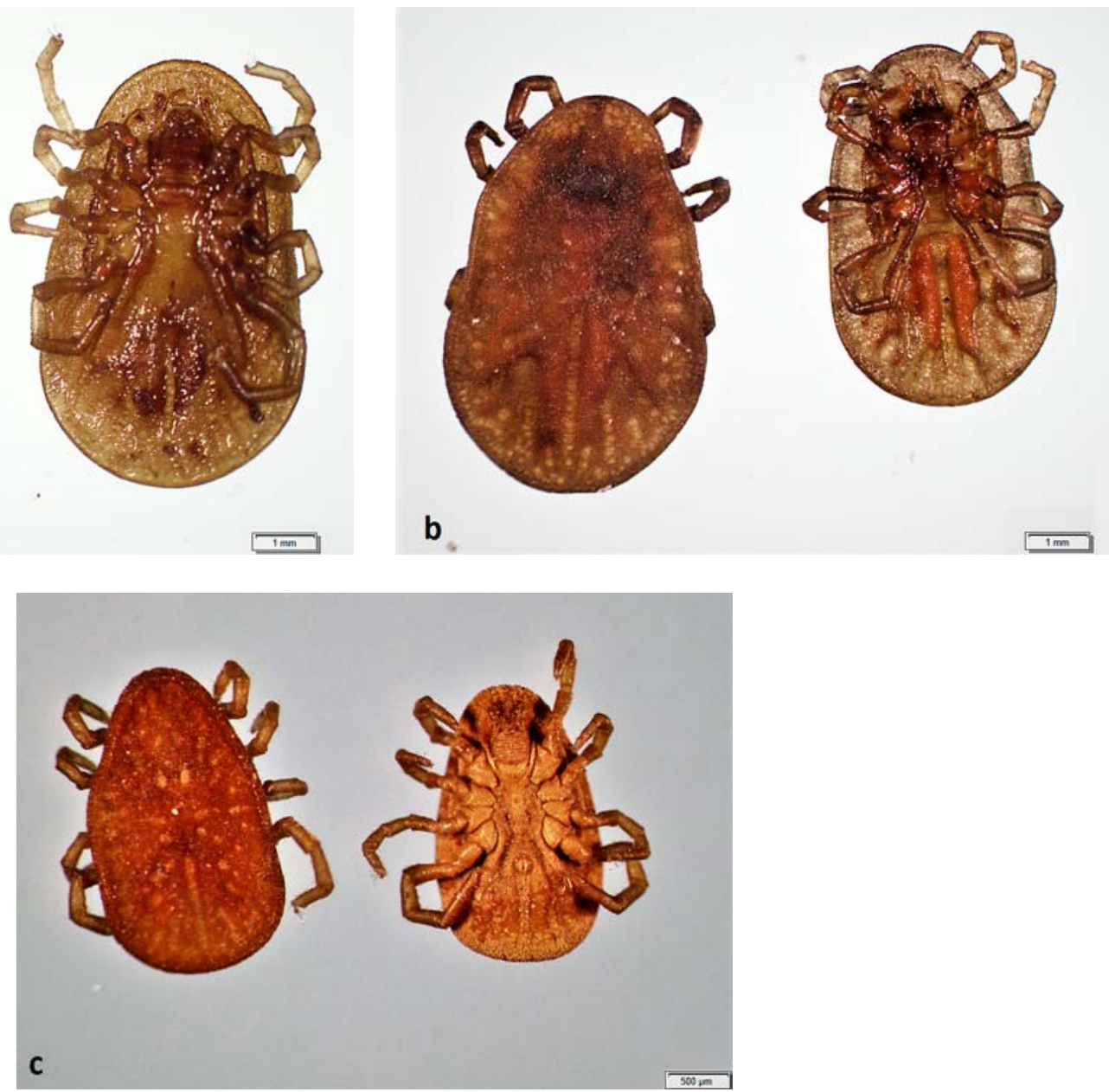

Figure 2. A. reflexus stages infesting humans most frequently.

A - unengorged females ( $8.34 \pm 1.15 \mathrm{~mm}$ body length, $5.48 \pm 0.67 \mathrm{~mm}$ body width); $\mathrm{B}$ - unengorged males $(6.60 \pm 0.79 \mathrm{~mm} \times 4.23 \pm 0.60 \mathrm{~mm}) ; \mathrm{C}-\mathrm{nymphs}$ (the size depends on the nymphal stage).

Silesian Province with a total area of $12,333.09 \mathrm{~km}^{2}$ and with $2,903,812$ inhabitants [34].

A. reflexus ticks were collected during the day, mainly in wall cracks and slits in the wooden ceilings of attics (Fig. 2). Each time, ticks were collected for one hour. Specimens collected were placed in transport chambers and next viewed under a stereoscopic microscope in laboratory conditions. The species, stage of development, and gender of adult ticks were determined in accordance with the identification keys proposed by Siuda [17].

Simultaneously, the residents of the buildings were interviewed to obtain information on skin lesions appearing after a night's sleep. To confirm the presence of pigeon ticks in the flats of the individuals reporting skin symptoms, cracks in the walls, furniture, and floor as well as other places that could be hides for the arthropods were carefully inspected. Photographic documentation was made of the residents' skin lesions.

\section{RESULTS AND DISCUSSION}

Table 1 shows the results of the collection of $A$. reflexus ticks in selected localities in the Upper Silesian conurbation. A total of 987 A. reflexus specimens were collected: 334 females, 269 males, and 384 various nymphal instars (88 nymphs I and 296 other nymphal instars). During one hour, 38-109 A. reflexus specimens were collected in the attics of the residential buildings. In most cases, a few or several dozen nymphs and adults (females and males) of this species were found per one crack. The accumulation of $A$. reflexus individuals is caused by the activity of pheromones released by these ticks [35]. Adult stages dominated in the majority of the collection events. Females and males accounted for $33.8 \%$ and $27.2 \%$, respectively, of all $A$. reflexus specimens collected during these investigations (Tab. 1). Older nymphal instars dominated among the nymphs. In this study, neither the number of nymphal instars in the Silesian A. reflexus population nor their morphometric characteristics were determined. A greater number of nymphs I than that of the other nymphal instars were noted only at the end of September. During the field study conducted in spring and autumn, no A. reflexus larvae were found in the wall cracks in the lofts of the buildings.

The structure of $A$. reflexus populations in different months of the year is related to the biology of this tick species. In spring, females usually oviposit after intake of pigeon's blood. In the absence of a host, they can lay small egg batches utilising nutrient reserves accumulated during the feeding period before the onset of the diapause (autogenous egg development) [11]. The length of the preoviposition, oviposition, and embryogenesis increases with the decline in 
Table 1. Frequency of occurrence of various Argas reflexus stages in the different localities during $1 \mathrm{~h}$ collection

\begin{tabular}{|c|c|c|c|c|c|c|c|}
\hline \multirow[b]{2}{*}{ Location/city } & \multirow[b]{2}{*}{$\begin{array}{l}\text { Collection } \\
\text { No. }\end{array}$} & \multirow[b]{2}{*}{ Period of study } & \multicolumn{4}{|c|}{ Developmental stage } & \multirow[b]{2}{*}{ Total } \\
\hline & & & $\begin{array}{c}\text { Females } \\
\text { Unengorged/ } \\
\text { engorged }\end{array}$ & $\begin{array}{c}\text { Males } \\
\text { Unengorged/ } \\
\text { engorged }\end{array}$ & $\begin{array}{l}\text { Nymphs I } \\
\text { Unengorged/ } \\
\text { engorged }\end{array}$ & $\begin{array}{l}\text { Nymphs } \\
\text { (other instars) } \\
\text { Unengorged/ } \\
\text { engorged }\end{array}$ & \\
\hline \multirow{2}{*}{$\begin{array}{l}\text { Katowice } \\
19^{\circ} 00^{\prime} \mathrm{E} 50^{\circ} 15^{\prime} \mathrm{N}\end{array}$} & $1^{*}$ & March/April 1996 & $8 / 0$ & $10 / 0$ & - & $10 / 0$ & 28 \\
\hline & 2 & March/April 1997 & $17 / 0$ & $10 / 0$ & - & $29 / 0$ & 56 \\
\hline \multirow{9}{*}{$\begin{array}{l}\text { Bytom } \\
18^{\circ} 54^{\prime} \mathrm{E} 50^{\circ} 23^{\prime} \mathrm{N}\end{array}$} & 2 & May 2002 & $19 / 0$ & $26 / 0$ & $7 / 0$ & $14 / 0$ & 66 \\
\hline & 3 & May 2002 & $41 / 3$ & $29 / 0$ & $11 / 0$ & $25 / 0$ & 109 \\
\hline & 4 & May 2002 & $20 / 2$ & $17 / 0$ & $3 / 0$ & $15 / 0$ & 57 \\
\hline & 5 & May 2002 & $24 / 1$ & $15 / 0$ & $5 / 0$ & $14 / 0$ & 59 \\
\hline & 6 & May 2002 & $14 / 0$ & $13 / 0$ & - & $17 / 0$ & 44 \\
\hline & 8 & May 2002 & $21 / 3$ & $18 / 0$ & $8 / 0$ & $12 / 0$ & 62 \\
\hline & 9 & May 2002 & $16 / 2$ & $13 / 0$ & $3 / 0$ & $15 / 0$ & 49 \\
\hline & 10 & May 2002 & $23 / 1$ & $13 / 0$ & $5 / 0$ & $12 / 0$ & 54 \\
\hline & 11 & May 2002 & $11 / 0$ & $12 / 0$ & - & 15 & 38 \\
\hline $\begin{array}{l}\text { Dąbrowa Górnicza } \\
19^{\circ} 16^{\prime} \mathrm{E} 50^{\circ} 19^{\prime} \mathrm{N}\end{array}$ & 1 & March/April 1995 & $15 / 0$ & $8 / 0$ & - & $24 / 0$ & 47 \\
\hline \multirow{2}{*}{$\begin{array}{l}\text { Świętochłowice } \\
18^{\circ} 55^{\prime} \mathrm{E} 50^{\circ} 19^{\prime} \mathrm{N}\end{array}$} & 1 & March/April 1995 & $18 / 0$ & $15 / 0$ & - & $15 / 0$ & 48 \\
\hline & 2 & March/April 1995 & $15 / 1$ & $10 / 0$ & - & $24 / 1$ & 51 \\
\hline \multirow{3}{*}{$\begin{array}{l}\text { Chorzów } \\
18^{\circ} 57^{\prime} \mathrm{E} 50^{\circ} 18^{\prime} \mathrm{N}\end{array}$} & $1^{*}$ & April 1996 & $2 / 0$ & $10 / 0$ & - & - & 12 \\
\hline & 2 & September 2000 & $13 / 0$ & $18 / 0$ & $20 / 0$ & $13 / 0$ & 64 \\
\hline & 3 & September 2000 & $6 / 1$ & $4 / 0$ & $19 / 0$ & $11 / 0$ & 41 \\
\hline $\begin{array}{l}\text { Total } \\
\%\end{array}$ & & & $\begin{array}{l}318 / 16(334) \\
32.2 / 1.6(33.8)\end{array}$ & $\begin{array}{c}268 / 1(269) \\
27.1 / 0.1(27.2)\end{array}$ & $\begin{array}{c}88 / 0(88) \\
9 / 0(9)\end{array}$ & $\begin{array}{l}295 / 1(296) ; \\
29.9 / 0.1(30)\end{array}$ & $\begin{array}{l}969 / 18(987) ; \\
98.2 / 1.8(100)\end{array}$ \\
\hline
\end{tabular}

* Collection time sorter than 1 hour; $\mathrm{n}-$ No. of collected specimens

ambient temperature [36-38]. It is probable that temperature determines the length of the developmental period and the number of nymphal instars $[9,39]$. As reported by Dautel and Knülle [39], in localities of $A$. reflexus in Berlin, nymphs II, nymphs I and larvae fed later than mid-July, August, or September, respectively. They enter the diapause when engorged.

Field observations carried out by one researcher from our team $(\mathrm{AB})$ in Upper Silesia indicate that nymphal instars and the adult stage of the pigeon tick usually survive the winter diapause period. However, it cannot be ruled out that larvae may have been present deep inside cracks that were not accessible during the study. In laboratory conditions, the potential of unengorged larvae to survive even for more than 100 days was confirmed.

The greater number of $A$. reflexus nymphs I in our autumn collections is associated with the presence of specimens moulted from larvae hatched from eggs oviposited by foraging females during the spring of the same year $[11,39]$.

The ticks found during collection were usually unengorged (Tab. 1). The highly flattened body and absence of food in the intestines of these specimens suggested a long starvation period. The presence of the great numbers and different developmental stages of $A$. reflexus in the lofts and attics of the inspected buildings suggested that the sites had been colonised by the ticks for a long time. Many pigeons were present inside the buildings, as well as on the roofs and window sills. As indicated by ornithological data, the greatest numbers of pigeons inhabit old buildings located in cities and lower numbers live in suburban and rural areas [40]. Both the number of pigeons and flocks, which are related to the occurrence of the European pigeon tick, as mentioned above, depend on the structure of buildings located in cities [40]. The localities of the A. reflexus ticks reported in this study were found in old buildings dating back to the beginning of the $20^{\text {th }}$ century.

Since researchers employ different research approaches in terms of specimen collection, seasons or months of the year, length of the collection period, and examined area, comparison of the abundance of $A$. reflexus populations in the occurrence range of this species is impossible. The greatest number of localities of the European pigeon tick has been reported from southern [e.g. 3, 24, 25, 41-44], western [e.g. 8, 26, 45, 46], and central [e.g. 9, 13, 30] Europe. Mayer [13] reported finding as many as 23,640 specimens of this tick species in one attic of a Berlin building, which had been a nesting site for approximately 100 pigeons. In 1982-1985, one of the authors of the presented study (AB) collected over $150 \mathrm{~A}$. reflexus nymphs and adults stages in an area of approx. $12 \mathrm{~m}^{2}(6 \mathrm{~m} \times 2 \mathrm{~m})$ of cracks and patches of plasterwork falling from the attic walls of a 1910 neo-Baroque building in Katowice.

European pigeon tick specimens were also found in other localities in the area of the Upper Silesian conurbation (Fig. 1). The research indicates the presence of $A$. reflexus ticks in many downtown buildings inspected in this study. Their spread in this region of Poland is associated with the multigenerational tradition of breeding pigeons, which 
probably started at the beginning of the $20^{\text {th }}$ century and gained wide popularity after World War I when Silesians working in Westphalia (Germany), or served in the German army in Belgium and returned to Upper Silesia after the end of the war. They popularised pigeon breeding not only in dovecotes but also in the attics of residential buildings.

Besides the availability of hosts, the presence of $A$. reflexus ticks in lofts and attics is supported by favourable thermal and humidity conditions, as confirmed by laboratory $[11,36,47-49]$ and field studies [39, 50]. Oviposition and embryonic larval development in the Silesian $A$. reflexus population take place at a temperature range of $20-30^{\circ} \mathrm{C}$ and $10-90 \%$ humidity, with optimal conditions of $20-25^{\circ} \mathrm{C}$ and $10-75 \%$ humidity [36]. Temperature fluctuations [37], low temperature [38], and high humidity [48] disturb the development of this species.

The $A$. reflexus adults and nymphs were collected during their peak seasonal activity, which is noted as March - June $[22,24,36,51]$, and during autumn, when the activity of these stages in northern and central Europe is lower. The greatest number of $A$. reflexus attacks on humans is recorded in spring when unengorged specimens leave their hiding places and start foraging $[22,46]$.

During the current study, skin lesions were reported by residents of Bytom, Chorzów, Dąbrowa Górnicza and Swiętochłowice. In this period, no cases of tick attacks were reported from Katowice. This can be explained by the fact that the building of the Silesian University was the inspected locality, which was uninhabited during the time of the nocturnal activity of the species. However, skin lesions caused by an $A$. reflexus bite and persistent swelling of the bitten area had been reported earlier by a man working in the evenings and at night in the University laboratory [10]. In turn, in the other A. reflexus habitat in Katowice, pigeon ticks had permanent access to many pigeons in lofts; therefore, they did not forage in flats.

\section{CASE REPORTS}

Case 1. A female patient was attacked by pigeon ticks in her flat and it was possible to trace the development of skin lesions caused by the tick bites. The observations made and the patient's history indicated slight inflammatory reactions appearing already in the morning, which intensified over subsequent days. A grey-purple rash formed at the bite sites. After 14 days, an intense inflammatory response to the tick bites was diagnosed. A purple papule appeared in the centre of the lesion. After the consecutive 76 days, a small ulceration with a slightly undetermined edge developed (Fig. 3, 4). No microbiological analyses were carried out, which could have excluded bacterial superinfection of the skin damaged by the A. reflexus chelicera and hypostome.

The patient claimed that she had also observed skin lesions resolving within one week in previous years. A. reflexus ticks were found in the loft of the building and the patient's apartment, which confirmed that the skin lesions were caused by their bites.

Case 2. Between March - July, a male patient was repeatedly infested by pigeon ticks during sleep, as indicated by postinflammatory hyperpigmentation after earlier bites (Fig. 5) and information provided by the patient. Frequent attacks of

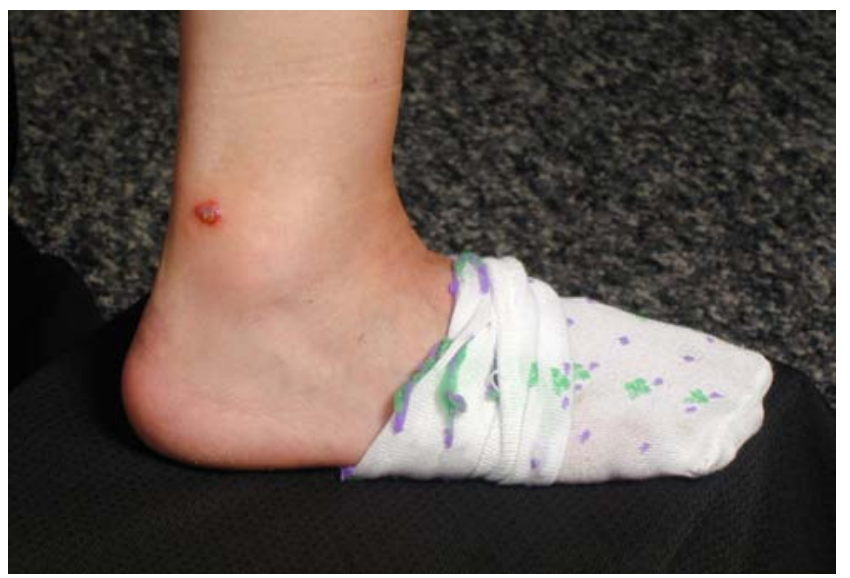

Figure 3. Solitary red nodule with small erosion in the centre of the lesion on oedematous base on lower extremity of a female. Formed 14 days after being bitten by $A$. reflexus

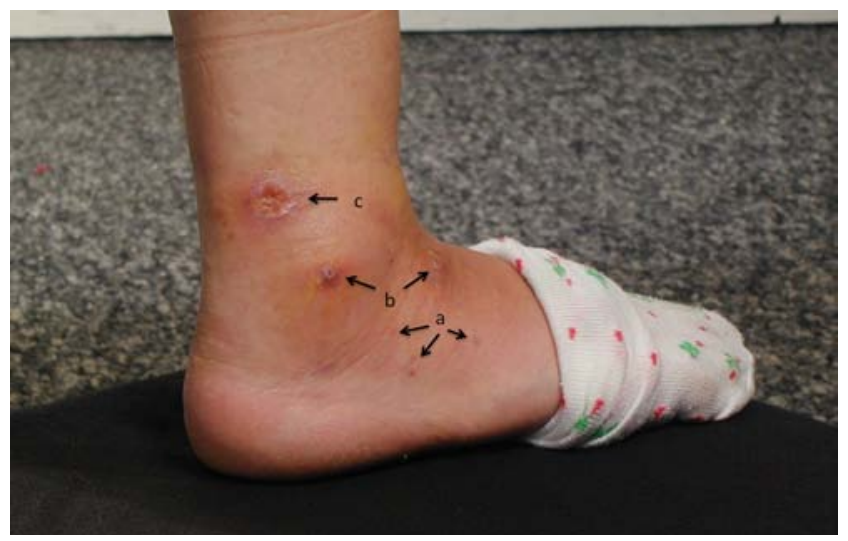

Figure 4. Multiple purple papules (a), nodules with small erosion in the centre of the lesion (b), and small ulceration with slightly undermined edge (c) formed approximately three months after being bitten by $A$. reflexus

the patient by these ticks were also noted during the presented study period. Multiple papules on an erythematous base developed at the bites on the lower extremities (Fig. 5, 6).

As in case 1 , many $A$. reflexus ticks were found in the building (attic and staircase), and in the patient's flat.

The above two cases and the presented multi-year observations indicate that the skin lesions caused by

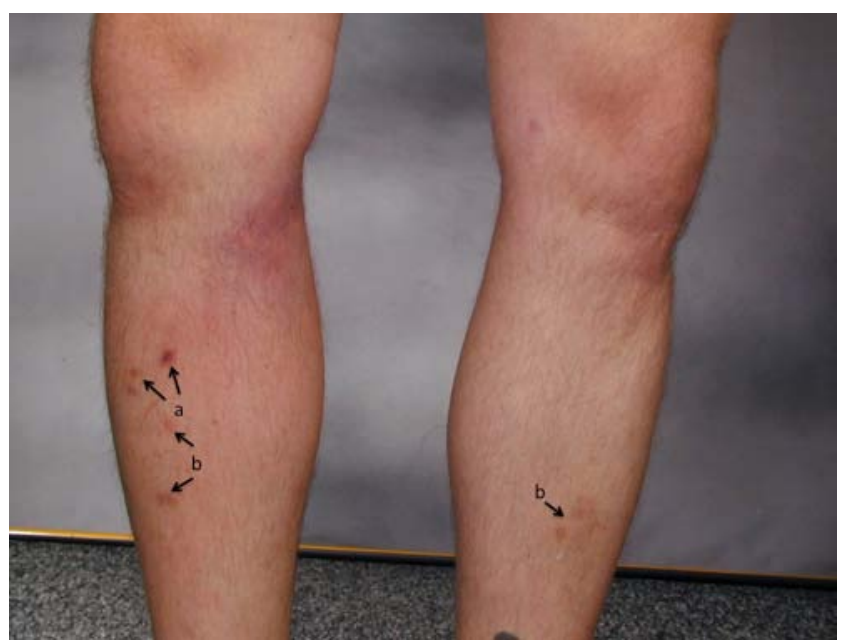

Figure 5. Multiple papules (a) on erythematous base on lower extremities of a male after being bitten by A. reflexus. Post-inflammatory hyperpigmentation (b) after earlier bites 


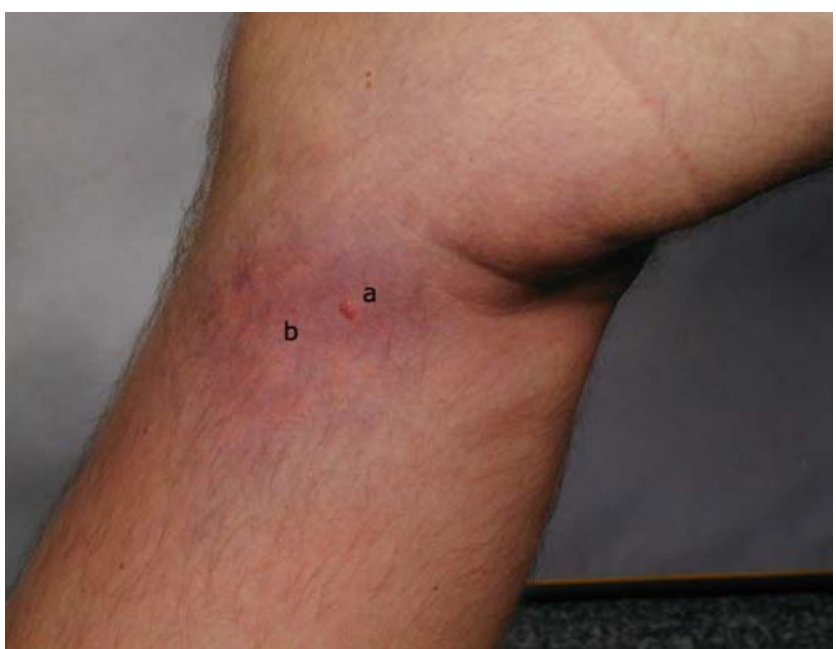

Figure 6. Solitary red papule (a) on erythematous and oedematous base (b) on the lower extremity of a male after being bitten by A. reflexus

A. reflexus bites are similar, but their range, severity, and dynamics of development may differ between patients. In some patients, very severe immune reactions and/or bacterial superinfection at the $A$. reflexus feeding site can be followed by the development of scars. In the cases described in this study, the skin lesions persisted for a long time, which was probably associated with development of hypersensitivity to A. reflexus toxins in both patients.

Depending on the frequency and intensity of pigeon tick attacks and patients' physiological condition, skin lesions caused by $A$. reflexus may resolve after several days [25] (own observations) or persist for either 2-3 weeks [52], or even 1.5 year after the bite $[10,53]$.

Local reactions induced by $A$. reflexus bites can be manifested by various symptoms, e.g. redness, itching, inflammatory node, enlargement and pain of lymph nodes, lymphatic secretions, wheal, pruritic secretion, lymphangitis, lymph node swelling, and vesicles [6, 19, 46, 53-56].

Laboratory tests have confirmed that $A$. reflexus bites cause IgE-mediated sensitizations and anaphylactic reactions in humans $[7,46,57,58]$. Literature provides descriptions of cases of anaphylactic shock caused by the components of tick saliva $[10,41,46,56,59]$, including a case of death of a man who was attacked four times by pigeon ticks [10]. In Upper Silesia, hypersensitivity in humans manifested by local or systemic allergic reactions developed in approximately $40 \%$ of subjects bitten by $A$. reflexus [7].

Systemic reactions to the components of $A$. reflexus saliva included urticaria, angioedema, vascular dysregulation, dyspnoea, unconsciousness, gastrointestinal symptoms (loss of appetite, nausea, vomiting, abdominal pain and diarrhoea, rectal tenesmus), rush and pruritus, and elevated body temperature $[10,24-26,41,53,56,60]$. The infestation by A. reflexus is a stress-inducing factor [25] (own observations). In addition to skin lesions, both patients described in this study reported other symptoms caused by A. reflexus bites, e.g. itching, malaise, headaches, nausea, lack of appetite, and agitation.

Given the high risk posed to human health, the effects of pigeon tick bites arouse great interest among medical doctors and students, and prompt the necessity for developing efficient strategies for a reduction in the abundance of these ticks in the urban environments.

\section{CONCLUSIONS}

The European pigeon ticks A. reflexus are spread in the lofts and attics of old buildings located in the centre of cities of the Upper Silesian conurbation, which are the localities for pigeons, i.e. their hosts. In subjects repeatedly infested by the European pigeon tick, severe inflammatory reaction caused by tick saliva components and purple papules with necrosis in the centre of the lesion can develop. Strong immunological reactions to $A$. reflexus tick bites and/or bacterial superinfections of damaged skin may lead to the formation of scars, as well as skin hyperpigmentation. The severity of local symptoms in patients repeatedly attacked by pigeon ticks and the persistence of skin lesions produced by $A$. reflexus bites causing discomfort, necessitate the undertaking of measures to limit tick bite cases by developing efficient methods for control of the abundance of ticks and pigeons in residential buildings, and for a comprehensive educational campaign in the area of occurrence of these parasites.

\section{Acknowledgement}

The authors thank Ms. Krystyna Kubicka for her help in collecting research material.

\section{REFERENCES}

1. Nowak- Chmura M. 2013. Tick fauna (Ixodida) of Central Europe. Scientific Publishing House of the Pedagogical University, Krakow (in Polish).

2. Petney TN, Pfäffle MP, Skuballa JD. An annotated checklist of the ticks (Acari: Ixodida) of Germany. Syst Appl Acarol. 2012; 17(2): 115-170.

3. Murillo JMS, Martín JMC, Curdi JL, Pacheco DP, Alarcón-Elbal PM. La garrapata de la paloma Argas reflexus (Fabricius, 1794) (Ixodida: Argasidae). Primera cita en Extremadura (España) e implicaciones en el ámbito de la sanidad animal y la salud pública. Rev Ibér Aracnol. 2013; 23: 103-108.

4. Haag-Wackernagel D. Gesundheitsgefährdungen durch die Straßentaube Columba livia: Parasiten. Amtstierärztlicher Dienst und Lebensmittelkontrolle. 2008; 3: 174-188.

5. Benoit-Bazille H. L'Argas reflexus (Fabr.) et son parasitisme chez l'homme. Mem Soc Zool Fr. 1910; 22(3): 261-280.

6. Hilger C, Bessot JC, Hutt N, Grigioni F, De Blay F, Pauli G, Hentges F. IgE-mediated anaphylaxis caused by bites of the pigeon tick Argas reflexus: cloning and expression of the major allergen Arg r 1. J Allergy Clin Immunol. 2005; 115(3): 617-622.

7. Śpiewak R, Lundberg M, Johansson GO, Buczek A. Allergy to pigeon tick (Argas reflexus) in Upper Silesia, Poland. Ann Agric Environ Med. 2006; 13(1): 107-112.

8. Gothe R, Imhoff N. Zur Infestation mit obligat-ektoparasitischen Arthropoden spp. bei Brieftauben in Deutschland. Ber Münch Tierärztl Wschr. 1975; 88(22): 431-436.

9. Dusbábek F, Rosický B. Argasid ticks (Argasidae, Ixodoidea) of Czechoslovakia. Acta Sci Nat Brno. 1976; 10(7): 1-43.

10. Buczek A, Solarz K. Attacks of humans by Argas (A.) reflexus (Fabricius, 1794) - dangerous human and animal parasites. Pol Tyg Lek. 1993; 48(9-10): 238-239 (in Polish).

11. Buczek A. Fecundity and reproductive activity of Argas (A.) reflexus (Fabricius, 1794) (Acari: Ixodida: Argasidae). Wiad. Parazytol. 1993; 39(1): 49-57 (in Polish).

12. Boxler B, P. Odermat, Haag-Wackernagel D. Host finding of the pigeon tick Argas reflexus. Med Vet Entomol. 2016; 30: 193-199.

13. Haag-Wackernagel D. Parasites from feral pigeons as a health hazard for humans. Ann Appl Biol. 2005; 147: 203-210.

14. Kemper H, Reichmuth W. Die Taubenzecke als Parasit des Menschen. Z Ang Entomol. 1941; 28(2-3): 507-516.

15. Filippova NA. Argasovye kleshchi (Argasidae). Fauna SSSR, Paukoobraznye. 4 (3). "Nauka" Izv Akad Nauk SSSR. Moskva, Leningrad, 1966 (in Russian). 
16. Siuda K. Review of data on the occurrence in Poland of ticks of the genus Argas (Acarina: Ixodides: Argasidae). Wiad Parazytol. 1984; 30(5-6): 595-601.

17. Siuda K. Ticks (Acari: Ixodida) of Poland. Part II Taxonomy and Distribution. Polish Society for Parasitology. Warsaw, 1993 (in Polish).

18. Buczek A. Characteristics of Argas (A.) reflexus (Fabricius, 1794) (Acari: Ixodida: Argasidae)- a common parasite in Upper Silesia. Wiad Parazytol. 1991; 37(3): 375-380 (in Polish).

19. Dautel H, Kahl O, Knülle W. The soft tick Argas reflexus (Acari: Argasidae) in urban environments and its medical significance in Berlin (West). J Appl Entomol. 1991; 11: 380-390.

20. Buczek A, Bartosik K. Occurrence of Argas reflexus (Fabricius, 1794) (Ixodida, Argasidae) in urban habitat of south-eastern Poland. Wiad Parazytol. 2011; 57(4): 277-279.

21. Buczek A, Bartosik K, Szymańska J, Buczek S. Pigeon tick Argas reflexus (Ixodida: Argasidae) in south-western Poland - biological features and clinical symptoms. Zdr Publ. 2011; 121(4): 422-425 (in Polish).

22. Dautel H, Kahl O, Scheurer S, Knülle W. Seasonal activities of the pigeon tick Argas reflexus (Acari: Argasidae) in Berlin, Germany. Folia Parasitol. 1994; 41: 155-160.

23. Grzybek A. Dzikowski A, Stefański E. Argas reflexus in Zabrze. Proceedings of XI Symposium of the Polish Parasitological Society, Poznań. 1973: 53 (in Polish).

24. Manilla G, Carluci G. Sull'invasione di Argas (A.) reflexus (Acari, Ixodoidea, Argasidae) in un'abitatione centrale di L'Aquila (Fotochemico-recettori e ruolo patogeno). Riv Parassitol. 1985; 46: 197-206.

25. Tosti A, Peluso AM, Spedicato S. Utricaria-angioedema syndrome caused by an Argas reflexus sting. Contact Dermatitis. 1988; 19(4): 315-326.

26. Laubstein B, Herold D, Audring H, Buchholtz I. Nächtliche Anaphylaxie durch Argas reflexus (Taubenzecke). Allergol Jahr. 1993; 16: 370-373.

27. Buczek A, Magdoń T. The pigeon tick Argas reflexus (Fabr.) in urban environments of Poland. Acta Parasitol. 2000; 45(3): 215.

28. Karbowiak G, Supergan M. The new locality of Argas reflexus Fabricius, 1794 in Warsaw, Poland. Wiad Parazytol. 2007; 53(2): 143-144.

29. Izdebska JN, Fryderyk S, Kentzer B. A mass occurrence of the European pigeon tick Argas reflexus (Acari, Argasidae) in Gdańsk. In: Buczek A, Błaszak C, editors. Arthropods. Influence on host. Koliber, Lublin; 2008. p. 47-50.

30. Haag-Wackernagel D, Bircher AJ. Ectoparasites from feral pigeons affecting humans. Dermatology. 2010; 220(1): 82-92.

31. Przybylska K, Haidt A, Myczko Ł, Ekner-Grzyb A, Rosin ZM, Kwieciński Z, Tryjanowski P, Suchodolska J, Takcs V, Jankowiak Ł, Tobółka M, Wasilewski O, Graclik A, Krawczyk AJ, Kasprzak A, Szwajkowski P, Wylęgała P, Malecha AW, Mizera T, Skórka P. Local and landscape-level factors affecting the density and distribution of the Feral Pigeon Columba livia var. domestica in an urban environment. Acta Ornitol. 2012; 47(1): 37-45.

32. Jokimaki J, Suhonen J. Distribution and habitat selection of wintering birds in urban environments. Landscape and Urban Planning. 1998; 39(4): 253-263.

33. Sol D, Santo D, García J, Cuadrado M. Competition for food in urban pigeons: the cost of being juvenile. Condor. 1998; 100: 298-304.

34. Knowledge Databases of Central Statistical Office of Poland, Available from: http://swaid.stat.gov.pl/EN.

35. Buczek A. Aggregation pheromones in adult forms of Argas (A.) reflexus (Fabricius, 1794) (Acari: Ixodida: Argasidae). Ann Acad Med Siles. 1991; 23: 137-141 (in Polish).

36. Buczek A. Studies on the biology of Argas (A.) reflexus (Fabricius, 1794) (Acari: Ixodida: Argasidae). I. Effect of temperature and relative humidity on embryonic development and egg hatch. Folia Biol (Krakow). 1988; 36(3-4): 239-263.

37. Buczek A. Studies on the biology of Argas (A.) reflexus (Fabricius, 1794) (Acari: Ixodida: Argasidae). 2. Effect of altering temperatures on embryonic development and egg hatch. Folia Biol (Krakow). 1992; 40(3-4): 151-153.

38. Buczek A. Effect of low temperature on the embryonic development and egg hatch of Argas (A.) reflexus (Fabricius, 1794) (Acari: Ixodida: Argasidae). Z Angew Zool. 1992/1993; 2: 249-254.

39. Dautel H, Knülle W. Life cycle and seasonal development of postembryonic Argas reflexus (Acari: Argasidae) at two thermally different location in central Europe. Exp Appl Acarol. 1997; 12(10): 697-712.

40. Sacchi R, Gentilli A, Razzetti E, Barbieri F. Effects of building features on density and flock distribution of feral pigeons Columba livia var. domestica in an urban environment. Can J Zool. 2002; 80(1): 48-54.

41. Miadonna A, Tedeschi A, Leggiero E, Falagiani P, Nazzari M, Manzoni M, Zanussi C. Anaphylactic shock caused by allergy to the venom of Argas reflexus. Ann Allergy. 1982; 49(5): 293-294.

42. Dal Monte A, Pajello M. Anaphylaxis due to a sting by Argas reflexus (the pigeon tick) A case report. Recenti Prog Med. 1994; 85(7-8): 384-386 (in Italian).

43. Khoury C, Maroli M. The pigeon tick, Argas reflexus, and hazard for human health. Sanita Ann Ist Super. 2004; 40(4): 427-432 (in Italian).

44. Rolla G, Nebiolo F, Marsico P, Guida G, Bigo P, Riva G, Zanotta S. Allergy to pigeon tick (Argas reflexus): demonstration of specific IgEbinding components. Int Arch Allergy Immunol. 2004; 135(4): 293-295.

45. Lavaud F, Bouchet F, Mertes PM, Kochman S. Allergy to the bites of blood-sucking insects: clinical manifestations. Allerg Immunol (Paris). 1999; 31(9): 311-316 (in French).

46. Kleine-Tebbe J, Heinatz A, Gräser I, Dautel H, Hansen GN, Kespohl S, Rihs HP, Raulf-Heimsoth M, Vater G, Rytter M, Haustein UF. Bites of the European pigeon tick (Argas reflexus): Risk of IgE-mediated sensitizations and anaphylactic reactions. J Allergy Clin Immunol. 2006; 117(1): 190-195.

47. Buczek A. Disturbances in larval hatch in Argas (Argas) reflexus (Fabricius, 1794)(Acari: Ixodida: Argasidae) caused by the influence of various thermal and humidity conditions. Wiad Parazytol. 1991; 37(1): 35-40.

48. Buczek A. Influence of high relative humidity on course of embryonic development and egg hatch of Argas (A.) reflexus (Fabricius, 1794) (Acari: Ixodida: Argasidae). Z Angew Zool. 1991; 4: 339-443.

49. Buczek A. Disturbances of embryonic development and egg hatch of Argas (A.) reflexus (Fabricius, 1794) (Ixodida: Argasidae) caused by altering temperatures. In: Kropczyńska D, Boczek J, Tomczyk A, editors. The Acari. Physiological and ecological aspect of Acari- host relationships. Publishing House Dabor, Warszawa; 1995. p. 351-355.

50. Dautel H, Knülle W. Seasonal oviposition and temperature requirements of eggs may limit northern distribution of European Argas reflexus (Acari: Argasidae). J Med Entomol. 1998; 35(1): 26-37.

51. Buczek A. Morphological variability of Argas (A.) reflexus (Fabricius, 1794) (Acari: Ixodida: Argasidae) females and males from a Silesian population. Z Angew Zool. 1993; 79(4): 409-419.

52. Chomicz L, Walski M, Turkowicz M, Zawadzki PJ, Kubica- Biernat B, Szubińska D, Dąbrowska J. Varied skin changes in people attacked by parasitic arthropods belonging to orders Simulium (Insecta, Diptera), Ctenocephalides (Insecta, Siphonaptera) and Argas (Arachnida, Acarina). In: Buczek A, Błaszak C, editors. Arthropods in medicine. Liber, Lublin; 2002. p. 205-213.

53. Kemper H, Reichmuth W. Die Taubenzecke als Parasit des Menschen. II. Beitrag: Über die Wirkung des Zeckenstiches auf die menschliche Haut. Z Hyg Zool Schädlingsbekämpf. 1941; 11/12: 184-193.

54. Wegner Z. Two new cases of bird mite (Acarina: Argasidae and Dermanyssidae) parasitism on humans in Poland. Wiad Parazytol. 1973; 19(2): 187-191 (in Polish).

55. Veraldi S, Barbareschi M, Zerboni R, Scarabelli G. Skin manifestation caused by pigeon ticks (Argas reflexus). Cutis. 1998; 61(1): 38-40.

56. Sirianni MC, Matiacci G, Barbone B, Mari A, Aiuti F, Kleine-Tebbe J. Anaphylaxis after Argas reflexus bite. Allergy. 2000; 55(3): 303.

57. Trautmann A, Amschler A, Schultz KD, Brecker EB, Klein CE. Anaphylactic reactions caused by pigeon ticks. Dermatosen. 1995; 43: 215-218.

58. Weckesser S; Hilger C; Lentz D, Jakob T. Anaphylactic reactions to bites of the pigeon tick Argas reflexus. Eur J Dermatol. 2010; 20(2): 244-245.

59. Bessot JC, Kopferschmitt MC, Deblay F, Dietemann A, Nirrengarten A, Hutt N, Lecoz C, Bouzouba A, Saintelaudy J, Pauli G. Anaphylactic shock after pigeon tick bite. Rev Fr Allergol Immunol Clin. 1997; 37(4): 431-437.

60. Demain JG. Papulary urticaria and things that bite in the night. Curr Allergy Asthma Rep. 2003; 3(4): 291-293. 